\title{
Evaluation of Porphyridium purpureum and Nannochloropsis sp. for Carbohydrates and Lipids Production
}

\begin{abstract}
ELENA EMILIA OPRESCU ${ }^{1}$, CRISTINA EMANUELA ENASCUTA ${ }^{1 *}$, ANA MARIAGALAN ${ }^{1}$, MIHAELA BOMBOS ${ }^{1}$, GABRIEL VASILIEVICI ${ }^{1}$, GABRIELA ISOPENCU ${ }^{2}$, VASILE LAVRIC ${ }^{2}$, SANDA VELEA ${ }^{1}$

${ }^{1}$ National Research \& Development Institute for Chemistry and Petrochemistry-ICECHIM, 202 Splaiul Independente, 060021, Bucharest, Romania,

2University Politehnica Bucharest, Faculty of Applied Chemistry and Materials Science, 1-7 Polizu Str., 011061, Bucharest, Romania

This study was aimed to evaluate the growth conditions of Porphyridium purpureum and Nannochloropsis sp. microalgae for carbohydrates and lipids productivity increase. The cultivation experiments for both microalgae strains were done in triplicates using the artificial seawater (ASW) as culture media. The lipids were separated from the algal biomass and the exo-polysaccharides content from the supernatant. The results showed that the highest carbohydrate content is found in Porphyridium purpureum while the highest lipid content was found in biomass.
\end{abstract}

Keywords: microalgae, polysaccharides, lipid, Porphyridium purpureum, Nannochloropsis sp.

Renewable liquid biofuels carbon-neutral are needed to partially replace petroleum-derived fuels because they have a negligible contribution to climate change and can be continuously regenerated, while the conventional fuels are depleting nonstop [1]. New, renewable energy sources, such as microalgae may become useful raw-materials in biofuels and biorefinery, due to their many advantages, including sustainable growth, high photosynthetic efficiency, areal productivity and oil content; also, they have the potential advantage of being harvested daily. Moreover, they do not compete with agricultural areas, and sources of potable water [2].

The competition for microalgae as a source of renewable fuel has launched many research studies starting from the selection of more productive species, improvement of cultivation set-up and conditions, and downstream efficient processing. Many of these studies aimed to increase productivity, and to decrease the costs, while improving the environmental balance [3]. Microalgae can be fractionated into carbohydrates, proteins, and lipids, which can be converted into a wide variety of high-value end-products with applications into diverse industrial sectors. For instance, from carbohydrates can be obtained nutraceuticals, cosmeceuticals, and biogas [4], from proteins, aquaculture and animal feedstock $[5,6]$, while from lipids biodiesel, biosolvents [7], pigments, antioxidants or antibacterial substances [8,9].

The screening of microalgal candidates for lipid and/or carbohydrate production targets high growth rates, elevated lipid/carbohydrate content, proper fatty acids composition, good environmental adaptability and contamination resistance. According to these aforementioned criteria, two very interesting strains of microalgae from the saline water habitat were identified: Nannochloropsis sp. and Porphyridium purpureum.

The genus Nannochloropsis has Nannochloropsis oculata as the type species. The species of Nannochloropsis sp are characterized by small size cells with a simple morphology. They typically live in habitats with saltwater (the exception being $\mathrm{N}$. limnetica). The five species of the genus are: N. oculate, N. salina, N., N. granulata and
N. limnetica. Nannochloropsis species are widely used as food in aquaculture and recently have been proposed for the commercial production of eico-sapentaenoic acid (EPA) especially and other fatty acids [10]. EPA has a key role in the prevention of atherosclerosis and cardiovascular diseases, in reducing plasma cholesterol and triacylglycerol levels and attenuating inflammatory conditions such as arthritis [11].

The red algae Porphyridium cruentum, synonym with Porphyridium purpureum, is a very promising candidate microorganism for producing fatty acids, lipids, carbohydrates, and pigments [2]. Porphyridium purpureum is a unicellular red microalga from Rhodophyta class which has the potential to produce large amounts of proteins (28$39 \%)$, polysaccharides (40-57\%) and lipids (9-14\%) subsumed into dry algal mass. This strain is unique in building up fluorescent phycobiliproteins, exopolysaccharides, long-chain polyunsaturated fatty acids, carotenoids (zeaxanthin, tocopherol, etc.) and vitamins during its metabolic processes [12]. These compounds can be used in cosmetics, health food, drugs, agriculture $[13,14]$ as well as at industrial level as thickeners, stabilizers and emulsifiers due to their gelling properties $[15,16]$.

In this context, the aim of the present study was to evaluate the potential of two microalgae species: Porphyridium purpureum and Nannochloropsis sp. for carbohydrates and lipids production and to search for those operating conditions of growth enable to ensure the increase of their productivity in the interest end-products.

\section{Experimental part}

Materials and methods

Methanol, reagent grade, min. 99,9\%, chloroform reagent grade, $\mathrm{Mg}\left(\mathrm{NO}_{3}\right)^{2} \cdot 6 \mathrm{H}_{2} \mathrm{O}, \mathrm{NaNO}_{3^{\prime}} \mathrm{K}_{2} \mathrm{SO}_{4}, \mathrm{NaHCO}_{3}$ $\mathrm{K}_{2} \mathrm{HPO}_{4}, \mathrm{NaCl}, \mathrm{MgSO}_{4} \cdot 7 \mathrm{H}_{2} \mathrm{O}, \mathrm{CaCl}_{2} \cdot 2 \mathrm{H}_{2} \mathrm{O}$, all reagent grade, were purchased from Scharlab S.L. Spain.

\section{Inoculum and culture media}

Inoculum of Porphyridium purpureum and Nannochloropsis $s p$. were originally obtained from the 


\begin{tabular}{|l|c|c|}
\hline \multicolumn{1}{|c|}{ Algae Strain } & Nannochloropsis $s p .$, & Porphyridium purpureum \\
\hline Cellular concentration, cell $/ \mathrm{mL}$ & $3.413 \cdot 10^{6}$ & $1.206 \cdot 10^{6}$ \\
\hline Optical density & $0.73 \pm 0.08$ (at $540 \mathrm{~nm})$ & $0.72 \pm 0.09$ (at $750 \mathrm{~nm}$ ) \\
\hline Dry Biomass, g/L & $0.71 \pm 0.02$ & $1.5 \pm 0.01$ \\
\hline
\end{tabular}

Table 1

DATA ON CELLULAR CONCENTRATION AND OPTICAL DENSITY collection of algal strains of University Babes Bolyai, Cluj Napoca, Romania. Both strains were grow th using artificial seawater (ASW) as culture medium with the following composition: $15.0 \mathrm{~g} / \mathrm{L} \mathrm{NaCl} ; 3.05 \mathrm{~g} / \mathrm{L} \mathrm{MgSO}_{4} \cdot 6 \mathrm{H}_{2} \mathrm{O} ; 2.8 \mathrm{~g} / \mathrm{L}$ $\mathrm{MgCl}_{2} \cdot 6 \mathrm{H}_{2} \mathrm{O} ; 0.75 \mathrm{~g} / \mathrm{L} \mathrm{CaCl}_{2} \cdot 2 \mathrm{H}_{2} \mathrm{O} ; 1.0 \mathrm{~g} / \mathrm{L} \mathrm{KNO} ; 0.08 \mathrm{~g} / \mathrm{L}$ $\mathrm{KH}_{2} \mathrm{PO}_{4} ; 0.54 \mathrm{~g} / \mathrm{L} \mathrm{NaHCO}_{3}$ (sterilized by autoclavation) and $1 \mathrm{~mL} / \mathrm{L}$ of trace metal solution:2.8 $\mathrm{g} / \mathrm{L} \mathrm{H}_{3} \mathrm{BO}_{3}, 2.03 \mathrm{~g} / \mathrm{L}$, $\mathrm{MnSO}_{4} \cdot 4 \mathrm{H}_{2} \mathrm{O}, 0.222 \mathrm{~g} / \mathrm{L} \mathrm{ZnSO} \cdot 7 \mathrm{H}_{2} \mathrm{O}, 0.018 \mathrm{~g} / \mathrm{L} \mathrm{MOO}(85 \%)$, $0.079 \mathrm{~g} / \mathrm{L},{ }^{2} \mathrm{CuSO}_{4} \cdot 5 \mathrm{H}_{2} \mathrm{O}$ and $\left.0.494 \mathrm{~g} / \mathrm{L} \mathrm{CO}(\mathrm{N})_{3}\right)_{2} \cdot 6 \mathrm{H}_{2} \mathrm{O}$, previously mixed with $1 \mathrm{~mL} / \mathrm{L}$ of chelated iron solution $(0.69$ $\mathrm{g} \mathrm{FeSO} \cdot 7 \mathrm{H}_{2} \mathrm{O}+0.93 \mathrm{~g} \mathrm{Na}$ EDTA in $80 \mathrm{~mL}$ demineralized water) sterilized by filtration with $0.2 \mathrm{~mm}$ PTFE filter [12].

\section{Algal biomass cultivation and harvesting}

The algal biomass cultivation tests were performed in $100 \mathrm{ml}$ aerated bottles adding $2 \mathrm{~mL}$ of inoculum to $50 \mathrm{~mL}$ of sterilized culture medium. The flasks were supplemented with $0.05 \mathrm{~mL} / \mathrm{L}$ of the micronutrient solution and $0.05 \mathrm{~mL} / \mathrm{L}$ of chelated iron solution. The cultivation experiments for both microalgae strains were done in triplicates using an orbital shaker-Incubator ES-80 which provide an agitation of $100 \mathrm{rpm}$, at environmental temperature and light intensity of approximately 18W/30. When the cultures reached the end of cultivation time, biomass was separated from the culture medium by centrifugation at 10000 rpm for 20 min, using a Hettich Rotina 380R centrifuge.

\section{Growth Measurements}

The optic density expressed as absorbance, was performed using a spectrophotometer UV-VIS UItra 3600 Rigol by reading the absorbance at $750 \mathrm{~nm}$ wavelengths for Porphyridium purpureum and $540 \mathrm{~nm}$ wavelengths for Nannochloropsis sp. The morphologyand the cells counting were done with a Motic microscope with a Moticam 3+ high-resolution ( 3 megapixels) using Thoma cell counting chamber. The cell concentration was calculated by the following formula:

Total cells $/ \mathrm{mL}=($ Total cells counted $\mathrm{x}$ dilution factor $\mathrm{x}$ 10000 cells/mL)/number of squares

\section{Lipid extraction}

The algal lipid fraction was extracted and characterized by the method detailed in Galan et. al., [17]

\section{Polysaccharides extraction}

The exo-polysaccharides content from the supernatant obtained after centrifugation of Porphyridium purpureum biomass was extracted following the protocol detailed in Patel et.al. [13] using 99\% Ethanol with ratio 1:1 EtoH : Supernatant in a $50 \mathrm{~mL}$ tube. Afterwards the tube was shaken for 5 minutes and stored in at $-20^{\circ} \mathrm{C}$ for $12 \mathrm{~h}$. After storage the sample was centrifuged at 5000 rpm for 10 min [18]. Carbohydrate content from algal biomass was quantified as glucose equivalent according to phenolsulfuric acid method [19].

\section{Results and discussions}

Growth measurements

Both strains were grown using ASW as culture medium. Data refer to cellular concentration and optical density, both parameters are shown in Table 1. As can be seen, after 10 days of cultivation, Nannochloropsis sp. reached the highest cellular concentration $\left(3.413 \cdot 10^{6} \mathrm{cell} / \mathrm{ml}\right)$ and optical density $(0.73 \pm 0.08)$, while Porphyridium purpureum exhibited the lowest cellular concentration $\left(1.206 \cdot 10^{6} \mathrm{cell} / \mathrm{mL}\right)$ and optical density $(0.72 \pm 0.09)$. Regarding biomass production, for Porphyridium purpureum were obtained $1.50 \pm 0.01 \mathrm{~g} / \mathrm{L}$, an almost double value compared to Nannochloropsis sp., $0.71 \pm 0.02 \mathrm{~g} / \mathrm{L}$. However, the highest biomass productivity was observed for Porphyridium purpureum strain, despite its low er optic density and cellular concentration values. Cell morphology image 40x of the two strains studied is presented in figure 1. In both cases, solitary or small clusters cell with smooth outer surface of plasma membrane were observed.

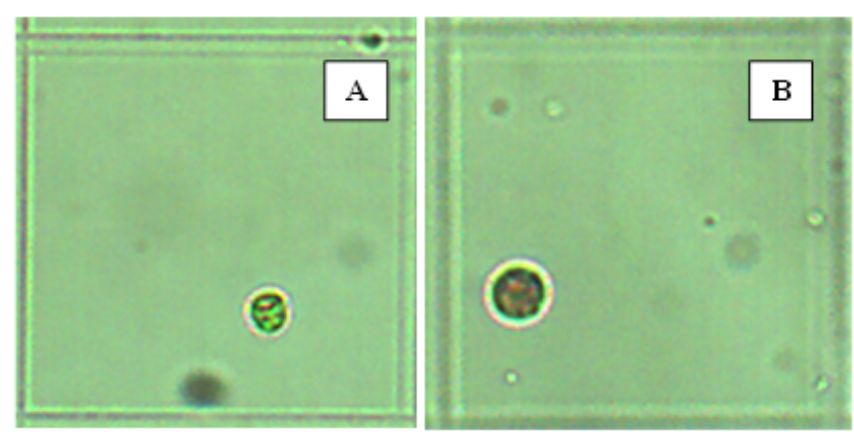

Fig. 1. Cells morphology image 40x of Nannochloropsis sp. (A) and Porphyridium purpureum (B)

\section{Total polysaccharides content}

The polysaccharide content is an intermediate reserve in some algae under chemical and physical stress. Carbohydrates tend to accumulate in the algae grow deprived of nutrients or light. The highest cell carbohydrate content of $13.20 \pm 0.05 \%$ was observed for Porphyridium purpureum, followed by Nannochloropsis sp., with $9.15 \pm 0.02 \%$ (Table 2). Under stress conditions Porphyridium purpureum strain has the ability to excrete in the culture medium exo-polysaccharide. In this study, the concentration of exo-polysaccharide extracted from culture media by precipitation with ethanol was $1.43 \pm 0.25$ $\mathrm{g} / \mathrm{L}$. These compounds serve as antiviral agents, health foods, antioxidants, they have anti-inflammatory properties and, also, a role in the immunomodulatory system; they

Table 2

EXPERIMENTAL RESULTS REGARDING DRY BIOMASS, EXOPOLYSACCHARIDES, CELL CARBOHYDRATES, LIPIDS

\begin{tabular}{|l|c|c|}
\hline Strain & Nannochloropsis sp. & $\begin{array}{c}\text { Porphyridium } \\
\text { purpureum }\end{array}$ \\
\hline $\begin{array}{l}\text { Exo- polysaccha- } \\
\text { rides, g/L }\end{array}$ & 0 & $1.43 \pm 0.25$ \\
\hline $\begin{array}{l}\text { Carbohydrates } \\
\text { from biomass (\%) }\end{array}$ & $9.15 \pm 0.02$ & $13.20 \pm 0.05$ \\
\hline Lipids (\%) & $52.07 \pm 0.07$ & $40.77 \pm 0.09$ \\
\hline
\end{tabular}


may also be used as lubricants for bone joints, or even as drag-reducing substances for ships [20-23].

\section{Lipid and fatty acid profiles}

The lipid content of the algal biomass was determined by thermogravimetric analysis. The lipids percent shown in Table 2 is composed of neutral lipid, glycolipid and phospholipid. The recorded thermogravimetric analyzes for the Porphyridium purpureum strain (figure 2) and Nannochloropsis sp., (figure 3) have the same decomposition profile. In the first step, at temperatures up to $100{ }^{\circ} \mathrm{C}$, the weight loss of the sample was very low. This slight decrease in sample weight is mainly due to the evaporation of moisture. From 100 to $250^{\circ} \mathrm{C}$, the loss of weight is due to evaporation of the volatile compounds present in the biomass sample. The maximum decomposition level of Porphyridium purpureum biomass was observed in the temperature range from 250 to 280 ${ }^{\circ} \mathrm{C}$, indicating loss of the lipid fraction, while for the Nannochloropsis sp. algal biomass, the degradation step corresponding to the lipid fraction was recorded in the temperature range from 297 to $305^{\circ} \mathrm{C}$. This small temperature difference can be explained by the different composition of the fatty acids present in the two algal oils, especially the saturated fatty acid content. Algal oil from Nannochloropsis sp. has a saturated fatty acid content of $43.26 \pm 0.41 \%$, and the Porphyridium purpureum algal oil has a percentage of $33.21 \pm 0.33 \%$. The highest lipid content was observed in Nannochloropsis sp. biomass followed by Porphyridium purpureum.

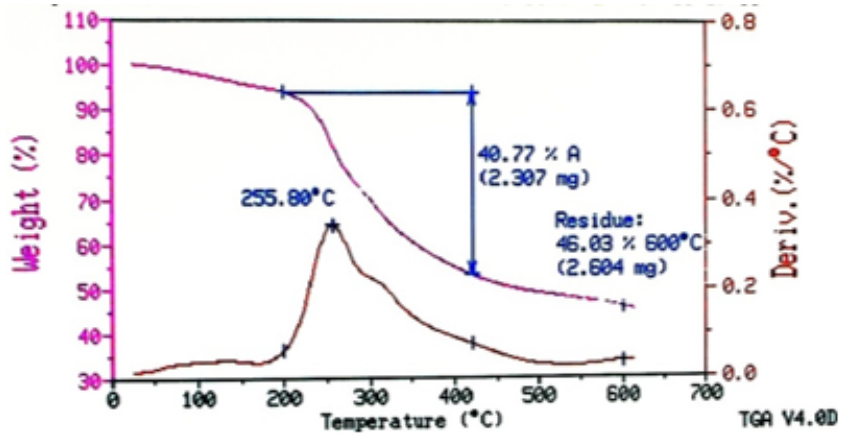

Fig. 2. TGA Profile of Porphyridium purpureum biomass

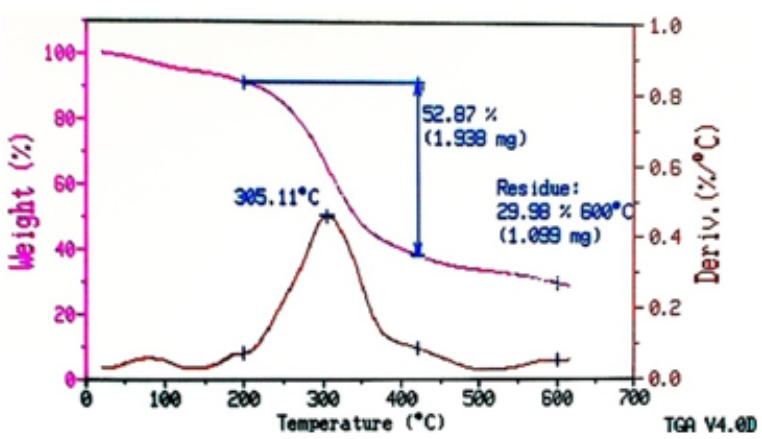

Fig. 3. TGA Profile of Nannochloropsis sp. biomass

The fatty acid distribution of algal oils extracted from the two algal strains is shown in Table 3. The highest content of saturated fatty acids is in the Nannochloropsis $s p$. $(43.26 \pm 0.41 \%)$ oil, followed by Porphyridium purpureum $(33.21 \pm 0.33 \%)$. With regard to the monounsaturated fatty acid content from the two the oil analyzed, again Nannochloropsis sp. has the highest content of $33.6 \pm 0.35 \%$ and Porphyridium purpureum of $6.8 \pm 0.21 \%$. Regarding the content of polyunsaturated fatty acids, the algal oil extracted from the strain Porphyridium purpureum has
$58.2 \pm 0.43 \%$, while that of Nannochloropsis sp. has $23.68 \pm 0.18 \%$.

Table 3

COMPOSITION OF FATTY ACIDS IN EXTRACTED ALGAL OILS

\begin{tabular}{|c|c|c|}
\hline Fatty acids & $\begin{array}{l}\text { Porphyridium } \\
\text { purpureum }\end{array}$ & Nannochloropsis sp. \\
\hline \multicolumn{3}{|c|}{ Saturated fatty acids, $\%$} \\
\hline $\mathrm{C} 14: 0$ & $0.21 \pm 0.02$ & $7.63 \pm 0.03$ \\
\hline C15:0 & $0.10 \pm 0.03$ & 0 \\
\hline $\mathrm{C} 16: 0$ & $32.7 \pm 0.10$ & $33.94 \pm 0.15$ \\
\hline $\mathrm{C} 17: 0$ & $\overline{0}$ & $0.1 \pm 0.02$ \\
\hline C18:0 & $0.20 \pm 0.01$ & $1.59 \pm 0.03$ \\
\hline \multicolumn{3}{|c|}{ Monounsaturated fatty acids, $\%$} \\
\hline C16:1 & $3.70 \pm 0.02$ & $23 \pm 0.21$ \\
\hline C18:1 & $3.10 \pm 0.02$ & $10.06 \pm 0.05$ \\
\hline \multicolumn{3}{|c|}{ Polyunsaturated fatty acids, $\%$} \\
\hline C18:2 & $8.30 \pm 0.03$ & $3.32 \pm 0.13$ \\
\hline C18:3 & $0.30 \pm 0.05$ & 0 \\
\hline C20:2 & $0.10=0.05$ & 0 \\
\hline C20:3 & $0.20 \pm 0.02$ & 0 \\
\hline $\mathrm{C} 20: 4$ & $19.30=0.23$ & $2.81 \pm 0.06$ \\
\hline $\mathrm{C} 20: 5$ & $30.00 \pm 0.36$ & $8.43 \pm 0.25$ \\
\hline $\mathrm{C} 22: 5$ & 0 & $1.33 \pm 0.06$ \\
\hline $\mathrm{C} 22: 6$ & 0 & $7.79 \pm 0.43$ \\
\hline
\end{tabular}

\section{Conclusions}

The aim of this work was to evaluate the potential of green microalgae Nannochloropsis sp. and red microalgae Porphyridium purpureum for carbohydrates and lipids production. The both strains were growth using artificial sea water as culture medium. The lipid and carbohydrate content of the algal biomass was determined by thermogravimetric analysis. The results showed that the two microalgae strains studied were capable to produce carbohydrates and lipids. The highest carbohydrate content of algal biomass was observed for Porphyridium purpureum, meanwhile the highest lipid content was determinate in Nannochloropsis sp. biomass. The fatty acid distribution of algal oils extracted from the two algal strains indicated that Nannochloropsis sp. oil has a saturated fatty acid content of $43.26 \pm 0.41 \%$, and the Porphyridium purpureum algal oil has a content of polyunsaturated fatty acids of $58.2 \pm 0.43 \%$.

Acknowledgement: The authors gratefully acknowledge the financial support of the UEFISCDI, Romania, in the framework of National Partnership Program, financing contract no. 104 PD/2018.

\section{References}

1.NOBRE, B.P., VILLALOBOS, F., BARRAGGN, B.E., OLIVEIRA, A.C., BATISTA A.P., MARQUES, P.A.S.S., MENDES, R.L., SOVOVA, H., PALAVRA, A.F., GOUVEI, L., Bioresour. Technol., no. 135, 2013, p.128.

2.HO, M. K., CHI, H. O., HYEUN-JONG, B.A, Bioresour. Technol., no. 233, 2017, p. 44.

3.PERRIER, B., CRAMPON, C., GUEZET, O., SIMON, C., MAIRE, F., LEPINE, O., PRUVOST, J., LOZANO, P., BERNARD, O., BADENS, E., Fuel, no. 153,2015, p. 640 .

4.RUOCCO, N.; COSTANTINI, S.; GUARINIELLO, S.; COSTANTINI, M., Molecules, no. 21, 2016, p.1.

5.MADEIRA, M.S.; CARDOSO, C.; LOPES, P.A.; COELHO, D.; AFONSO, C.; BANDARRA, N.M.; PRATES, J .A.M., Livest. Sci., no. 205, 2017, p.111. 6.BLEAKLEY, S.; HAYES, M., Foods, no. 6, 2017, p. 33.

7.VASSILEV, S.V.; VASSILEVA, C.G., Fuel, no. 181, 2016, p. 1.

8.CARDOZO, K.H.M.; GUARATINI, T.; BARROS, M.P.; FALCÃO, V.R.; TONON, A.P.; LOPES, N.P.; CAMPOS, S.; TORRES, M.A.; SOUZA, A.O.; COLEPICOLO, P.; Comp. Biochem. Physiol. Toxicol. Pharmacol., no. 146,2007, p. 61.

9.ELST, K., MAESEN M., JACOBS G., BASTIAENS L., VOORSPOELS ID S., SERVAES K., Molecules, no. 23, 2018, p.1854. 
10.XIAO-NIAN, M.A., TIAN-PENG, C., BO, Y., JIN, L., FENG, C.., Mar. Drugs, no. 14(61), 2016, p. 1.

11.CHINI ZITTELLI G., LAVISTA F., BASTIANINI A., RODOLFI L., VINCENZINI M., TREDICI M.R., J ournal of Biotechnology, no. 70, 1999, p. 299.

12.VELEA S., ILIE L., FILIPESCU L., U.P.B. Sci. Bull., Series B, no. 73(4), 2011, p. 81.

13.PATEL, A.K, LAROCHE C., MARCATI A., URSU A.V., JUBEAU S., MARCHAL L., PETIT E., DJ ELVEH G., MICHAUD P., Bioresour. Technol., no. 145,2013, p. 345.

14.ARAD, S., YARON, A., Trends. Food Sci. Technol., no. 3, 1992, p.92. 15.YOU, T., BARNETT, S.M., Biochem. Eng. J., no. 19, 2004, p. 251.

16.LUTZU, G.A., ZHANG, L., ZHANG Z., LIU, T., Bioprocess Biosyst. Eng., no. 40, 2017, p. 73.

17.GALAN, A.-M, CALINESCU, I., RADU, E., OPRESCU, E.-E., VASILIEVICI, G., VELEA, S., Rev. Chim.(Buchartest), 68, no. 4, 2017, p. 671.
18.FUENTES-GRUNEWALD C., C. BAYLISS, M. ZANAIN, C. POOLEY, M. SCOLAMACCHIA, A. SILKINA, Bioresour. Technol., no. 189, 2015, p. 357.

19. DUBOIS, M., GILLES, K. A., HAMILTON, J. K., REBERS, P. A., \& SMITH, F., Analytical Chemistry, no. 28, 1956, p. 350.

20.RAPOSO, M.F.J . COSTA DE MORAIS, R.M.A., BERNARDO DE MORAIS, A.M., Mar. Drugs, no. 11, 2013, p. 233.

21.CALIN, C., VASILE SCAETEANU G., MADJ AR R.M., CANGEA 0., Rev. Chim. (Bucharest), 68, no. 9, 2017, p. 2092.

22.ILIE L., MIHALACHE M., MADJAR R.M., CALIN C., SCAETEANU G. V., Rev. Chim.(Bucharest), 69, no. 3, 2018, p. 561.

23.STANCU, A., CALIN C., PANTEA, O., ENE C., Rev. Chim.(Bucharest), 66, no. 6, 2015, p.778.

$\overline{\text { Manuscript received: } 13.11 .2018}$ 